\title{
METHODOLOGY FOR THE GENERATION OF SCIENTIFIC PRODUCTS IN GOVERNMENT RESEARCH INSTITUTIONS
}

\section{WILVER AUCCAHUASI, EDGAR GUEVARA, ANGEL TONGO, LUCERO RODAS}

Comisión Nacional de Investigación y Desarrollo Aeroespacial del Perú, Lima, Perú

\begin{abstract}
Currently and due to the causes of the new normality that is being experienced in the world, many tasks are changing in the development of economic activities. The research topic is one of the fundamental axes that is operating as a mechanism to generate knowledge that can help improve the quality of life of people. The public administration has among its tasks the planning of the activities to be carried out, and these are mostly planned at least one year in advance, activities are planned as the expense or budget necessary to carry out these tasks. Taking as a reference the activities related to research and the generation of knowledge; Private and public institutions dedicated to the field of research must begin to carry out their sustained planning regarding the development of projects and the generation of scientific reports through the publication of scientific articles. Scientific articles are the mechanism and the indicator to measure and evaluate scientific production. In the present work a methodology is presented to be able to plan the research projects and their corresponding scientific production based on the presentation and publication of the scientific articles, taking into account the critical factor the time that the planning of the pres takes. The methodology presents the results that we must plan with at least one year to carry out the projects so that they can be entered in the budget for the following year. For the publication of results, a minimum of 2 years from the presentation of the project must be considered. The methodology also refers to the general processes that are mostly similar in public administration, where each of the processes to follow is developed until the final publication of the scientific articles.

KEYWORDS: Scientific article, Research, State companies Publication process
\end{abstract}

Received: Jun 08, 2020; Accepted: Jun 28, 2020; Published: Sep 24, 2020; Paper Id.: IJMPERDJUN20201405

\section{INTRODUCTION}

When carrying out a project we must take into account the entity where the project will be carried out and it is in this sense that we are faced with two situations, the first a private company and the second a public company, it is for this reason that the projects They will have many differences from the objective, financing to reach the observable products of the project. In the bibliography there are mostly projects related to the private sphere, where most of them are in charge of testing new strategies both in development and innovation, proposing many alternatives for better management of these practices in companies [1]. Most of the works that we can find in the bibliography on products obtained by research by the public sector, are related to the area of agriculture and its different products that are obtained, based on the Company-State relationship, whose objective is to improve of agricultural products improving productive capacities [2].

In the generation of the academic products that can be obtained with the influence of the State, they are related from the public Universities where the production of patents, scientific articles, theses, among others is measured [3]. Other approaches that are added to the research products by the State, through the National 
Universities, are those focused on the social aspect, which propose to improve mostly, improve the quality of life of people [4]. There are many attempts to improve research related indicators, one of them is related to education; also with the research-related infrastructure to enable the growth and application of scientific activities, as well as with the adaptation of an agenda that corresponds to being able to direct the direction of research [5]. We also find works on the analysis of influence by the different States of Latin America, where the relationship that the State has with science and Research is analyzed, based on indicators such as the growth of publications, the different capacities of States as knowledge-producing agent and how these affect society [6].

The present work is characterized by presenting a methodology based on the evidence of academic products such as the realization of the projects and their corresponding scientific publications, from the approach of state entities dedicated to scientific research, with emphasis on the planning of these activities. caused by budget availability that has to be considered well in advance.

\section{METHODS Y MATERIALS}

The proposed methodology is considered from the point of view of management in state institutions, where it has to be the main factor to carry out any type of activity or process, to be able to plan it in advance, normally this planning has to be done one year in advance of the process. In this sense, if any project is required, it must be planned and proposed so that it can be considered in the following year. One of the indicators of the level of research in most research institutions, whether public or private, is the number of scientific articles, it is for this reason that the subject of planning becomes more critical, since scientific articles are As a result of the research projects, given this measure there is a need to also plan the presentations of scientific articles for the development of institutional strategies in the process of improving the indicator of scientific publications.

The proposed methodology for this administrative challenge is to be able to present a methodology to plan the projects to be carried out, as well as the articles to be published with reference to budget availability and their corresponding planning. Figure 1 presents the block diagram of the proposed methodology.

Figure 1 shows the 6 processes indicated by the methodology, which begins with the presentation of the project and ends with the publication of the scientific articles, passing through each of the stages where time is an important factor, to Each of the stages of the proposed methodology is developed below.

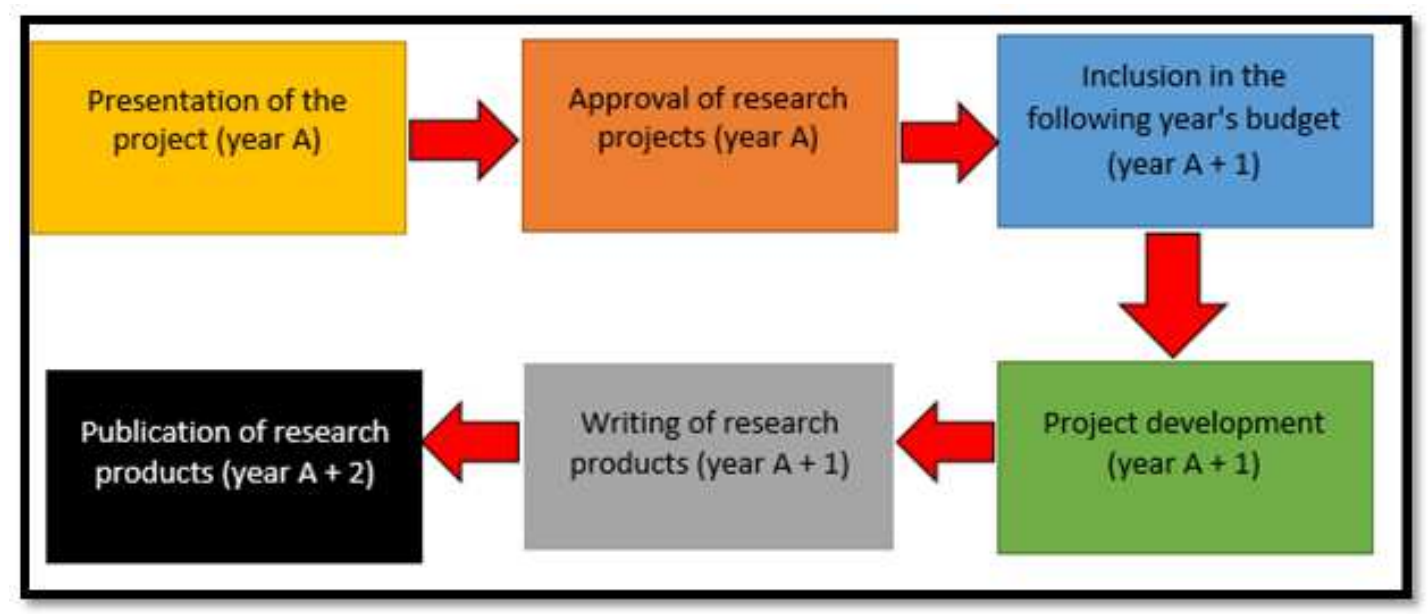

Figure 1: Proposal Block Diagram 


\section{PRESENTATION OF THE PROYECT (YEAR A)}

When we try to carry out a project in the different areas, it must be considered when we can present it. The presentation will depend on whether the institution has as research policies a call for the presentation of projects or otherwise it can be presented through an open window at any time of the year, in any case, according to the methodology it indicates that the year of the presentation is consider as initial year or year "A".

\section{APPROVAL OF RESEARCH PROJECTS (YEAR A)}

Once the project is presented, the next step is the approval of the project, this process can be done through a contest or approval individually of the project. The interesting part of this process is to keep in mind that all the projects to be developed in the next year are approved and must be included in the institution's budget for the following year. If this is not possible, it would have to be included in the budget for the coming years so that they can be included in order to have a source of financing. The year of project approval is considered the initial year or "A" year.

\section{INCLUSION IN THE FOLLOWING YEAR'S BUDGET (YEAR A+1)}

Having the projects approved, the next and essential process is to be able to be included in the institution's budget in order to ensure development in the following year, it is necessary to mention that until now only the project has been approved and put to evaluation and inclusion to obtain the corresponding financing. In the methodology model, the year where the project is included, where it has an assigned budget and the research is carried out, and will be where it has an assigned budget, is considered an "A + 1" year.

\section{PROYECT DEVELOPMENT (YEAR A+1)}

According to the presented methodology, we are in the year where we are working on the project and therefore one of the indicators where the results of the research are evident, are the publications of the scientific articles. Scientific articles have a different dynamic for publication, the process consists of writing, presenting, evaluating, accepting and finally publishing. With these characteristics in the process of publishing a scientific article, it is necessary to plan ahead from the writing to its publication. The year the project is carried out, according to the methodology, is the year "A + 1".

\section{WRITING OS RESEARCH PRODUCTS (YEAR A+1)}

The indicator of scientific production is the articles, therefore the publication process has many intermediate processes, according to the quality of the article, these can be presented in conferences or in the best case in a specialized magazine, each with Very long times between submission and publication, the methodology recommends starting the writing process, in parallel with the execution of the project, in order to have the article ready in the shortest time and when you have publishable results of the project. The methodology presented considers the writing stage of the scientific article as "A +1 " year.

\section{PUBLICATION OF RESEARCH PRODUCTS (YEAR A+2)}

The final stage of the article publication process, as an indicator of having carried out the project, is carried out starting with the writing, going through the review and acceptance and ending with the publication, all the processes have an expected time and can take several months. That is why it is recommended to start writing in parallel with the execution of the project. The approximate time considered in months for a publication is 3 months or more, depending on the journal or 
the congress, considering the start time where the project is presented according to the methodology is year " $\mathrm{A}$ " and the final time according to the methodology It is time when the scientific article is published in the magazine is the year "A + $2 "$.

\section{RESULTS}

The results presented in this work are related to the planning of technical-scientific activities of state institutions, which carry out their activities based on research projects and require publishing their results, in a normal situation, make their publications It is complicated as much by the delay in its process, as in the planning. In practice, it is verified that public institutions do not publish their work and research, some consider that they do not do research, but the issue is that they do not plan what discourages when they start the process and are aware that the publication time is on average 3 months to 20 months on average.

The methodology presented recommends that a planning process be carried out both for the development of projects and for the publication of scientific articles. The estimated time from the presentation of a project to the publication of scientific articles is an average of 2 years. This time will depend on the duration of the project. In the case of the methodology, it is considered that the projects should last an average of 1 year, the time necessary to dedicate it to the project due to budgetary considerations and the nature of government control.

\section{REFERENCES}

1. Candía, J. G., Coliñanco, L. G., Caro, C. L., \& Hernández, N. R. (2014). Estrategia y cultura de innovación, gestión de los recursos y generación de ideas: prácticas para gestionar la innovación en empresas. Pensamiento \& gestión, (36), 109-135.

2. Díaz, J. A. (2014). Comercialización de los productos y servicios de la ciencia: retos y perspectivas. Revista Cubana de Ciencia Agrícola, 48(1), 21-24.

3. López Leyva, S. (2010). Cuerpos académicos: factores de integración y producción de conocimiento. Revista de la educación superior, 39(155), 7-25.

4. Institucional, f. (2015). Proyectos de investigación. tablas dinámicas, retrospectiva institucional, investigación, recopilación de información.

5. Oszlak, O. (1997, October). La Administración Pública como área de investigación: la experiencia argentina. In ponencia presentada en la II Conferencia Internacional del CLAD sobre la Reforma del Estado, Isla Margarita, Venezuela.

6. Palamidessi, M. I., Gorostiaga, J. M., \& Suasnábar, C. (2014). El desarrollo de la investigación educativa y sus vinculaciones con el gobierno de la educación en América Latina. Perfiles educativos, 36(143), 49-66. 